\title{
ŠTEFAN POLAKOVIČ - SLOWACKI IDEOLOG I TEORETYK NARODU
}

\author{
ŠTEFAN POLAKOVIČ - SLOVAK IDEOLOGUE \\ AND THEORETICIAN OF NATION
}

\begin{abstract}
Štefan Polakovič is a leading representative of the philosophy of the people in Slovakia. The opinions of Š. Polakovič about the nation changed. In the early period of his work, he characterized the nation in terms of the organism. In his late works, he was examining the substance of the nation in terms of atomism and moderate individualism. The fundamental metaphysical thesis about the existence of the nation is the one that the nation, just like a man, is a creation of God. Hence, the nation has the tasks to be accomplished, designated by God. It is the duty of creative members of the nation to recognize the will of God in relation to the nation. Š. Polakovič in connection with the diversity of concepts of the nation recognized the need for existence of philosophical science of the nation - nationology. Nationology is to examine fundamental metaphysical, epistemological and axiological issues of the nation as incomparable with any other object.
\end{abstract}

Key words: philosophy; nation; nationality; learning about the nation

\section{Streszczenie}

Štefan Polakovič jest czołowym przedstawicielem filozofii narodu na Słowacji. Poglądy Š. Polakovicia na naród zmieniały się. We wczesnym okresie twórczości naród charakteryzowat on w kategoriach organizmu. W późnej twórczości analizowat istotę narodu $w$ kategoriach atomizmu i umiarkowanego indy-

TADEUSZ CHROBAK Uczelnia Jańskiego w Łomży, Łomża E-mail: chrobak@poczta.onet.eu This work was supported by the author's own resources. No competing interests have been declared.

This is an Open Access article distributed under the terms of the Creative Commons Attribution 3.0 PL License (creativecommons.org/licenses/by/3.0/pl/), which permits redistribution, commercial and non-commercial, provided that the article is properly cited. () The Author(s) 2015.

Publisher: Institute of Slavic Studies, Polish Academy of Sciences [Wydawca: Instytut Slawistyki PAN] 
widualizmu. Zasadniczą tezą metafizyczną dotyczącą istnienia narodu jest twierdzenie, że naród, tak jak człowiek, jest tworem Boga. Stąd też naród ma zadania do zrealizowania, wyznaczone mu przez Boga. Obowiązkiem twórczych członków narodu jest rozpoznanie woli Boga w stosunku do narodu. Š. Polakovič w związku z różnorodnością koncepcji narodu uznał, że konieczna jest filozoficzna nauka o narodzie - nacjologia. Nacjologia ma badać fundamentalne zagadnienia metafizyczne, epistemologiczne i aksjologiczne narodu, jako bytu nieporównywalnego z żadnym innym obiektem.

Słowa kluczowa: filozofia; naród; narodowość; nauka o narodzie

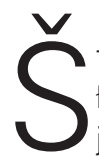

tefan Polakovič (1912-1999) należał do czołowych ideologów słowackiej myśli społecznej i narodowej w okresie I Republiki Słowackiej w latach 1939-1945. Podobnie jak Józef Tiso, prezydent i wódz I Republiki Słowackiej, nawiązywał do Sturowskiej (Sedlák, 1997) romantycznej wizji narodu. Zasadniczą przesłanką podjęcia problematyki narodu przez Š. Polakovicia była sytuacja polityczna, w jakiej znalazł się naród słowacki po rozpadzie I Republiki Czechosłowackiej.

Zagadnienia związane z istnieniem narodów, w szczególności narodu słowackiego, stały się dominującym przedmiotem dociekań filozoficznych Š. Polakovicia. jego poglądy w ciągu jego długiego życia ewoluowały, tak iż można mówić o dwóch różnych koncepcjach narodu. Pierwszej, związanej z powstaniem I Republiki Słowackiej, i drugiej, będącej oryginalną próbą stworzenia filozoficznej nauki o narodzie - nacjologii.

\section{NARÓD - AKTEM KREACJI WOLI BOŻEJ}

Koncepcja narodu Š. Polakovicia z okresu funkcjonowania państwa słowackiego w czasie II wojny światowej była ściśle związana z myślą społeczno-polityczną J. Tisy. Zależności między tymi koncepcjami są tak daleko posunięte, iż zachodzą trudności rozdzielenia treści tych propozycji intelektualnych. J. Tiso i Š. Polakovič przyjęli, iż podstawa istnienia narodów ma swoje źródło w rzeczywistości transcedentalnej. Powstanie i istnienie narodów związane jest z aktem kreacyjnym woli Bożej. Akt tworzenia narodów powiązany został przez nich ze stworzeniem człowieka przez Boga. Stworzenie narodu przez Boga ujawnia się w odrębności i oryginalności społeczno-kulturowej narodów. Każdy naród charakteryzuje specyficzny układ cech, właściwych tylko danemu narodowi. O odrębności i oryginalności poszczególnych narodów przesądza: biologiczna struktura społeczności narodowej mająca swoje źródło we wspólnym pochodzeniu plemiennym, „typ cielesności”, „Wspólnota krwi" i język. Z biologiczną odrębnością narodu powiązana jest swoista i niepowtarzalna kultura narodu, przejawiająca się w moralności społecznej, świadomości historycznej zapewniającej ciągłość życia narodu, w obyczajach, aspiracjach i zamierzeniach oraz w wizji przyszłości narodu. Trzecią grupą cech przesądzających o odrębności i indywidualność narodu jest fizyko-geograficzne ukształtowanie miejsca pobytu narodu na Ziemi. Składa się na nią topografia zasiedlanego obszaru oraz historycznie ukształtowany przez naród krajobraz - krajobraz apotropeiczny. Wymienione elementy, decydujące o specyfice narodu i odróżniające go od innych nacji, przyjmują w zasadzie wszystkie nacjonalizmy. Układ tych elementów o różnym sposobie istnienia sprawia, że tworzy się specyficzna 
świadomość grupowa narodu. Zrozumienie zawartości treści składających się zbiorową świadomość narodową jest niedostępne w pełni obcym etnicznie jednostkom. Natomiast dla członków wspólnoty narodowej treści świadomości narodowej dane są na zasadzie oczywistości, to zaś gwarantuje emocjonalną i intelektualną trwałość więzi łączących jednostki z narodem (Polakovič, 1941a, ss. 6-8).

Naród w koncepcji J. Tisy i Š. Polakovicia to przede wszystkim ludzka zbiorowość duchowa, spirytualna. Oznacza to, że zasadniczym warunkiem istnienia i rozwijania się narodu jest kreowanie i wzmacnianie jego potencjału i siły duchowej, spirytualnej (Polakovič, 1941a, s. 9). Moc duchowa narodu jest wypadkową dziejowej ciągłości tradycji narodowej, przejawiającej się w kulturze oraz religii i moralność. Siła tych czynników zapewnia ciągłość i trwałość egzystencji narodu począwszy od jego mitycznych prapoczątków poprzez teraźniejszość oraz w przyszłości.

Naturalnym spoiwem ciągłości istnienia narodu w przypadku narodu słowackiego stała się tradycja katolicka, a szerzej chrześcijańska. Obyczajowość i obrzędowość katolicka najmocniej wpisała się w dzieje narodu słowackiego. W procesie kształtowania się narodu słowackiego istotny wpływ na kształt jego duchowości wywarły inne Kościoły i wyznania chrześcijańskie. Z tego też powodu Š. Polakovič zwraca uwagę na chrześcijańską przynależność religijną narodu słowackiego. Przynależność do chrześcijaństwa przesądziła o jego moralnej tożsamości i jako taka stała się imperatywem postępowania członków narodu słowackiego.

Organiczna zależność genezy człowieka i narodów od bytu absolutnego - Boga osobowego - doprowadziła J. Tisę i Š. Polakovicia do stwierdzenia, iż sens życia jednostki ludzkiej, jak też sens istnienia narodu słowackiego określa religia, w szczególności religia katolicka, a szerzej chrześcijaństwo. Zaś wyróżniona pozycja religii katolickiej wynika z tego, że Kościół ten akcentuje fakt powołania do istnienia człowieka i narodu przez akt woli Bożej (Polakovič, 1941a, s. 28).

Naród, mając transcedentalną genezę swojego istnienia, jest jednocześnie bytem nadprzyrodzonym i naturalnym. Istniejąc, naród ma zadanie wypełniania Bożego planu zbawienia w przestrzeni rzeczywistości ziemskiej. Zgodnie też z wolą Bożą naród ma i powinien istnieć jako niezależny i wolny podmiot. Naród ma istnieć i realizować wolę Bożą analogicznie do człowieka, będącego bytem dysponującym wolną wolą i mającego możliwość dokonywania wolnych wyborów. Tożsamość genetyczna człowieka i narodu sprawia, że samodzielne i wolne istnienie narodu jest fundamentalnym zadaniem każdego narodu (Polakovič, 1941a, ss. 17-18). Brak niezależnej od innych nacji i wolnej egzystencji narodu jest sam w sobie sprzecznością. Powodowane to może być zarówno niesprzyjającą sytuacją międzynarodową, jak i nieopatrznymi poczynaniami członków narodu.

J. Tiso i Š. Polakovič, przyjmując niesprzeczność i jedność zasad chrześcijańskich oraz idei narodowych, dowodzili, że są to wzajemnie koherentne systemy filozoficzne i ideologiczne. Zasadniczą przesłanką uzasadniającą ten pogląd było odwołanie się do transcendentalnej, boskiej genezy człowieka i narodu. Konkluzją tych dociekań było twierdzenie, że konstytutywnymi formami istnienia narodu jest jego jedność i jednorodność. W ich rozumieniu naród tworzył homogeniczny byt społeczny. Przyjęcie radykalnej wizji homogeniczności narodu słowackiego wykluczało jego zróżnicowanie na klasy, warstwy, kasty społeczne, jak też istnienie mniejszości narodowych na terytorium zasiedlanym przez naród (Polakovič, 1941a, s. 12). Równocześnie ideolodzy ci nie mogli zaprzeczyć istniejącemu, wielorakiemu zróżnicowaniu społecznemu narodu słowackiego. Uznali też, że niwelowanie i zlikwidowanie zróżnicowania społecznego Słowacji to podstawowe zadanie 
narodu i państwa. Konsekwencją tego postulatu było potraktowanie wszelkich form indywidualizmu społecznego i jednostkowego jako zachowań egoistycznych, utrudniających osiągnięcie przez naród słowacki jednorodności i jedności. Alowiem w tej perspektywie teoretycznej sens życia jednostki ludzkiej wyznaczać miało swoiste "rozpłynięcie się" we wspólnocie narodowej i w działalności na rzecz narodu i państwa (Polakovič, 1941a, s. 18).

Zdaniem tych ideologów narodu nie była to jednak depersonalizacja jednostki ludzkiej. Miała to być natomiast naturalna, świadoma i aktywna postawa jednostek, służąca wzmacnianiu więzi społecznych i duchowej jedności narodowej. Dlatego też praktyczna i teoretyczna aktywność jednostek ludzkich w każdej sferze życia indywidualnego i społecznego miała ostatecznie służyć dobru narodu. W konsekwencji jednostka ludzka funkcjonować miała nie jako osoba prywatna z właściwymi sobie dążeniami i potrzebami, ale jako jednostka świadoma tego, że jej życie traci sens, gdy bezpośredni lub pośrednio nie służy ono interesowi i dobru narodu. Miała to być postawa samoograniczenia indywidualnego egoizmu i podporządkowania jednostkowej aktywności interesom wspólnoty narodowej.

W tym ujęciu teoretycznym przynależność narodowa jednostki nie może być przedmiotem wyboru. Naród jest bytem doskonalszym i nadrzędnym w stosunku do politycznych formy organizacyjnych narodu tącznie z państwem. Państwo zaś to tylko jedna z form przejawiania się autonomii i wolności narodu.

Mimo zasadniczych różnic między istnieniem narodu a politycznymi formami jego zorganizowania, Š. Polakovič będzie twierdzit, iż istotnym atrybutem narodu jest jego państwowość (Polakovič, 1941a, s. 24). W ówczesnym kontekście historycznym, bez własnej państwowości bardzo trudno byłoby realizować suwerenność narodową. Tym samym arystotelesowska koncepcja zoon politicon sprowadzona została do zasady utożsamienia różnych interesów i preferencji aksjologicznych poszczególnych jednostek z interesem państwa. Tym samym zasadę etatyzmu Š. Polakovič uznał za konstytutywny warunek jedność i trwałości narodu. Koncepcję tę można było zrealizować, za cenę ograniczenia indywidualnych, egoistycznych interesów poszczególnych członków narodu i wykluczenia z życia społecznego innych grup narodowościowych i mniejszości etnicznych.

Niewątpliwie też w koncepcji J. Tisy i Š. Polakovicia chrześcijański uniwersalizm został, jeżeli nie w warstwie teoretycznej to w praktyce, zredukowany do nacjonalistycznego partykularyzmu. Zdaniem tych ideologów narodu słowackiego, jednostka tylko poprzez miłość do narodu może w pełni doświadczyć miłości drugiej osoby i rodziny. Albowiem miłość bliźniego oznacza w pierwszym rzędzie miłość obejmującą członków własnego narodu i to nie jako osób prywatnych z właściwymi im cechami, ale członków narodu "jako takich". Tym samym tożsamość narodowa jednostek ludzkich jest nadrzędna zarówno w stosunku do jednostek ludzkich rozumianych jako osoby prywatne jak i innych niż naród zbiorowości społecznych.

Równocześnie J. Tiso i Š. Polakovič zwrócili uwage na powszechnie dostrzeganą prawidłowość, że miłość do narodu może przybrać skrajnie niepożądane formy, czego przejawem jest szowinizm narodowy. Narodowy szowinizm, jako zjawisko społeczne, można ograniczyć i wyeliminować w drodze perfekcjonistycznego respektowania zasad katolicyzmu. Wypełnianie w życiu publicznym i prywatnym religijnych oraz moralnych zasad katolicyzmu umożliwiać miało przezwyciężenie właściwego jednostkom ludzkim egoizmu i wynikającego z niego szowinizmu narodowego. Postulowane rozwiązanie miało, przynajmniej w pewnym zakresie, ograniczać właściwy nacjonalizmowi partykularyzm, który w I Republice Słowackiej przejawił się w skrajnych formach. 
Etniczna tożsamość wspólnoty narodowej kształtowana jest w procesie wielowiekowej trwałości kultury narodowej i dana w prawie naturalnym przysługującym każdemu narodowi. Wymaga to od państwa narodowego dbałości o czystość etniczną narodu, łącznie z korektą pierwotnych granic etnicznych narodu. Skumulowanie każdej rozproszonej przestrzennie wspólnoty narodowej na zwartym geograficznie obszarze, zdaniem tych teoretyków, miało pozytywnie oddziałać na stosunki międzynarodowe. Przeprowadzenie tego przedsięwzięcia dotyczyć miało całej Europy. A jego zrealizowanie miało się dokonać z poszanowaniem zasad równości i integralności poszczególnych narodów (Polakovič, 1941a, s. 180). W ujęciu J. Tisy i Š. Polakovicia nie oznaczało jednak przymusowego przemieszczania ludności. Ta propozycja rozwiązania kwestii etnicznych budzi wiele wątpliwości teoretycznych, szczególnie w świetle doświadczeń XX wieku, który obfitował w czystki etniczne przeprowadzone w Europie i innych częściach świata. Założenie, że wszystkie zainteresowane społeczności narodowe powrócą dobrowolnie na terytoria swojego pochodzenia, należy uznać za mało prawdopodobne.

W rozumieniu J. Tisy i Š. Polakovicia poczucie tożsamości narodowej ma wieczny i niezmienny charakter. Nie osłabia go upływ czasu ani przestrzenna separacja członków danego narodu. Zgodnie z tym twierdzeniem, dążenie do połączenia się z narodem i powrotem do geograficznego miejsca stworzenia narodu przez Boga jest pragnieniem naturalnym i niezmiennym dla każdego członka narodu żyjącego w diasporze. Z tym wyidealizowanym poglądem łączyć się mogła zimna kalkulacja polityczna, uzasadniająca działania na rzecz spełnienia tych pragnień.

W omawianej ideologii państwowości narodu słowackiego eksponowana była myśl, że droga do zbawienia i wypełnienia przez człowieka jego transcedentalnego przeznaczenia prowadzi poprzez naród. To zaś oznacza, że uniwersalne wartości humanistyczne są wartościami niższego rzędu w relacji do wartości narodowych, chociaż są wzajemnie powiązane. W tym ujęciu ideologicznym, osoba ludzka będzie zbawiona przede wszystkim jako członek narodu, a nie członek ludzkości. Wskazuje to na faktyczną nadrzędność interesów i wartości narodowych nad uniwersalnymi ideałami moralności chrześcijańskiej. Idee te na Słowacji ujęto w zawołaniu "naród ponad wszystko".

Powszechne łączenie w narracji politycznej w I Republice Słowackiej treści i symboli religijnych z interesami narodowymi wyrażone zostało w haśle "Bóg i Naród". Przesłanie to można interpretować zarówno jako formułę mającą minimalizować napięcia w obrębie narodu słowackiego jak i ostre konflikty etniczne mające miejsce w I Republice Słowackiej. Hasło to miało też uzasadniać moralną jedność polityki i religii. Zwłaszcza ta druga możliwość wysunęła się na czoło, jako następstwo decyzji z 14 marca 1939 roku. Autorytet moralny religii był jedną z przesłanek uzasadniających opowiedzenie się zgromadzenia posłów słowackich, zasiadających w sejmie czechosłowackim, za samodzielnością państwową narodu słowackiego.

Moralne przesłanie chrześcijaństwa „miłuj bliźniego swego jak siebie samego" musiato też ulec znacznemu osłabieniu wobec realizacji idei narodowej. Napięcie między uniwersalną normą miłości bliźniego a interesami narodu ujawniało się w kontekście struktury wyznaniowej społeczeństwa słowackiego. W związku z tym J. Tiso i Š. Polakovič przyjęli, że członków narodu słowackiego nie różnicuje przynależność religijna do Kościoła katolickiego i Kościołów ewangelickich (Polakovič, 1941b, ss. 11-12). Formuły tej nie można było zastosować do wyznawców judaizmu.

Katolików i ewangelików miała łączyć akceptacja tych samych zasad regulujących funkcjonowanie narodu i państwa słowackiego (Polakovič, 1941, ss. 44-46). To zróżni- 
cowanie wyznaniowe narodu słowackiego nie tylko nie podważało jedności narodu, ale zyskało polityczną akceptację. J. Tiso i Š. Polakovič mieli świadomość wkładu inteligencji luterańskiej w kształtowanie się słowackiej tożsamości narodowej w XIX wieku. Zwłaszcza dokonań Ludovita Štura i sturowców na drodze odrodzenia narodowego nie sposób było przecenić. Na wkład L. Štura w dzieło budzenia świadomości narodowej Słowaków wielokrotnie zwracał uwagę Š. Polakovič w rozważaniach poświęconych kodyfikatorowi pisanego języka słowackiego i wybitnemu ideologowi ruchu narodowego.

Dla J. Tisy i Š. Polakovicia naród jest żywym organizmem (Polakovič, 1941b, s. 8). Żaden naród nie może być i nie jest przypadkowym zbiorowiskiem osób, lecz organiczną całością, mającą zrealizować zadaną mu przez Boga misję. Organiczny charakter narodu związany jest z realizacją ostatecznego celu narodu, którym jest naturalny rozwój narodu. W organiczną całość wszystkich członków narodu łączy zarówno świadomość wspótistnienia, jak też wspólny cel i przeznaczenie. To właśnie przeznaczenie narodu ma kształtować mistyczną jedność i jest tą cechą narodu, która najwyraźniej odróżnia członków jednego narodu od członków innego narodu (Polakovič, 1941b, ss. 44-45). Świadczy o tym fakt, że chociaż poszczególni członkowie narodu nie komunikują się ze sobą bezpośrednio, to podzielają określone wartości i są przeświadczeni o wspólnocie interesów, co jest jednym z czynników przesądzających o specyfice i jedności narodu. Właśnie, w imię narodowej jedności i terytorialnej integralności, członkowie społeczności narodowej są gotowi pracować, cierpieć, umierać, jak też zabijać.

Świadomość mistycznej wspólnoty narodowej i uczestnictwa w odwiecznej jego misji, realizowanej w ścisłym połączeniu z narodową ideologią i chrześcijańskimi zasadami, miała mobilizować naród słowacki, szczególne w sytuacji zagrożenia. To wspólne doświadczenie pozwala na budowanie silnej więzi między elitami politycznymi i narodem w celu realizacji historycznej misji narodu. „Nie jesteśmy rycerzami chwilowej koniunktury, ale jesteśmy pracownikami i strażnikami wieczystych skarbów kulturowych, społecznych i gospodarczych kraju" (Polakovič, 1941b, s. 147). Efektem tego zaangażowania miało być wzmocnienie własnej pozycji jednostki, jej przydatności dla narodu i całej wspólnoty narodowej.

Mobilizujące oddziaływanie retoryki religijno-etniczno-etatystycznej miało istotne znaczenie w pierwszych latach istnienia I Republiki Słowackiej. Splot różnorodnych uwarunkowań wewnętrznych i zewnętrznych sprawiał, że istnienie narodu i państwa słowackiego było niepewne. Ideał immanentnej, supranaturalnej i ponadczasowej jedności wspólnoty narodowej pozwalał na pomniejszanie sprzeczności między narodowym partykularyzmem i wartościami uniwersalnymi. W oficjalnej państwowej narracji propagandowej wartości chrześcijańskie, a w szczególności katolickie, miały wyznaczać reguły funkcjonowania państwa i jego struktur.

\section{NACJOLOGIA - FILOZOFICZNA NAUKA O NARODZIE}

Po emigracji w 1945 roku ze Słowacji Š. Polakovič aktywnie uczestniczył w życiu Słowaków pozostających na emigracji i rozwijał badania związane z problematyką narodu. W rozprawie Eseje o narodie opublikowanej w 1998 roku przedstawił koncepcję nauki o narodzie, którą określit terminem nacjologia, będącym tłumaczeniem słowackiego terminu narodoveda. 
Š. Polakovič zauważa, że fenomen istnienia narodów zafascynował europejskich badaczy w ostatnich trzech stuleciach. Jednakże poznanie bytu, jakim jest naród, wymyka się stosowanym $w$ filozofii i nauce metodom poznania. W tym przypadku sytuacja poznawcza badacza jest analogiczna jak ma to miejsce w odniesieniu do poznania człowieka. Pomimo dociekań wielu nauk, które zajmują się badaniem człowieka, otwarte w dalszym ciągu pozostają pytania: kim ja jestem?, kim jest człowiek? (Polakovič, 1998a, s. 15). I tak samo jak wyjaśnienie fenomenu człowieka, na odpowiedź oczekuje też pytanie o genezę, istotę $\mathrm{i}$ istnienie narodu.

Š. Polakovič twierdzi, że dotychczasowe socjologiczne, antropologiczne, historyczne i filozoficzne badania narodu są cząstkowe i niedostateczne. I jak nie ma rozwiązania zagadki istnienia człowieka, podejmowanej począwszy od Gilgamesza poprzez Sokratesa, Platona, Arystotelesa do współczesnych filozofów, tak samo jest z problemem narodu.

Š. Polakovič wskazuje na pięć przyczyn tej sytuacji poznawczej. Po pierwsze, doświadczenie narodowości należy do podstawowego ludzkiego doświadczenia. Istnienie narodu ma głęboko ludzki wymiar, o czym świadczy to, że większość ludzi identyfikuje się z jakimś narodem. Po drugie, przynależność osoby ludzkiej do narodu określa zasadnicze wymiary jego życia duchowego, które nie dają się zastąpić innymi inwariantnymi. Etniczne wyobcowanie jednostek ludzkich jest z reguły źródłem głębokiej psychicznej, społecznej i kulturowej traumy. Po trzecie, brak właściwego i pełnego zrozumienia, czym jest naród, prowadzi w politycznie zorganizowanych społecznościach do ostrych napięć i kryzysów społecznych (Polakovič, 1998a, s. 17). Š. Polakovič podkreśla, że z problemami konfliktów etnicznych i narodowościowych borykają się europejskie państwa wielonarodowościowe, jak Belgia, Irlandia, Hiszpania, a co jest następstwem nieporozumień w zakresie rozumienia, czym jest narodu. Po czwarte, niesprawiedliwość etniczna jest przyczyną niestabilności sytuacji międzynarodowej i międzypaństwowej. Związane z tym konflikty i zbrojenia są przyczyną permanentnego zagrożenia pokoju międzynarodowego. Po piąte, pomimo tego, że wiele narodów oczekuje na uznanie swojej suwerenności, to równocześnie jest prawdą, że ludzkość weszła w epoke narodów, jak przewidywał Ludovit Štúr, a następnie Arnold Toynbee (Polakovič, 1998a, s. 17). Wymienione przez Š. Polakovicia przesłanki epistemologiczne wskazują na potrzebę określenia, czym jest naród, tym bardziej że w świadomości społecznej wzmacnia się przeświadczenie, iż właściwymi podmiotami prawa międzynarodowego są narody a nie państwa. Aby sprostać tym wymaganiom, potrzebna jest nowa dziedzina wiedzy mająca za przedmiot wyłącznie narody.

Według Š. Polakovicia tą nową dziedziną nauki jest nacjologia. Nacjologia jako nazwa nowego obszaru wiedzy jest neologizmem, który przede wszystkim określa przedmiot zainteresowań tej nauki. Nacjologia okazuje się być nauką współcześnie niezbędną, gdyż etnologia, etnografia, socjologia, socjografia, antropologia, archeologia, historia nie traktują narodu jako wyłącznego przedmiotu swoich badań. „Jej głównym zadaniem będzie przybliżyć się jak tylko to możliwe do samej istoty narodu jako takiej, do społecznego mianownika wszystkich narodów" (Polakovič, 1998a, s. 18). Tak zdefiniowaną wiedze o narodzie Š. Polakovič zalicza do obszaru wiedzy metafizycznej. Precyzuje przy tym, że metafizykę rozumie w sensie arystotelesowskim, co oznacza, że nacjologia jest w pierwszym rzędzie metafizyką i ontologią narodu „czyli dociekaniem bytu narodu” (Polakovič, 1998a, s. 18).

Inspiracją dla takiego określenia narodovedy przez Š. Polakovicia były, jak sam stwierdził, dociekania Ortegi y Gasseta, który rozważał zagadnienie narodowości. Badania narodu doprowadziły Ortegę y Gasseta do drugiej rzeczywistości (Polakovič, 1998a, s. 19). W związku z tym Š. Polakovič stawia pytanie o to, czym istnienie narodów różni się od 
istnienia innych bytów? Pytania tego Ortega y Gasset nigdy nie sformułował, chociaż był przeświadczony, że narody były, są i będą istnieć do końca czasów. „Tak jak istnieją narody, tak celem nauki o narodzie (nacjologii) jest badanie, jakie przesłanki musi spełniać jakaś grupa społeczna, abyśmy mogli określić ją jako naród" (Polakovič, 1998a, s. 19) stwierdza Š. Polakovič. Aby wykonać to zadanie, konieczne jest szczegółowe zbadanie wielu niejasności związanych z samym określeniem narodu.

Naród nie jest bowiem jakąś tam ludzką społecznością. Nie można go utożsamiać z klubem, którego członkostwo jest wolną decyzją zainteresowanej osoby, ze społecznością wyznaniową czy też innym agregatem społecznym. Chociaż jak zaznaczył Š. Polakovič, nazizm wprzągł religię do swojego wozu. Uwagę tę można traktować jako wyraz samokrytycznego odniesienia się Š. Polakoviča do idei , jakie rozwijał w okresie funkcjonowania I Republiki Stowackiej.

W drugim, emigracyjnym okresie swojej twórczości Š. Polakovič zauważył, że narodu nie można utożsamić ze społecznością polityczną ani z określoną przestrzenią geograficzną, krainą, czy też językiem. Niejasności związane określeniem narodu doprowadziły do patologicznych zjawisk społecznych, gdy biali i metysi ogłosili się narodem boliwijskim w Boliwii. Podobna sytuacja zaistniała w Paragwaju.

Współcześnie, jak twierdzi Š. Polakovič, narodowość jest trwałą i niezmienną jakością ludzkiej osoby zakotwiczoną w duchowości człowieka. Natomiast obywatelstwo danego państwa jest jakością przechodnią i może być wielokrotnie zmieniane, jak to jednostce ludzkiej pasuje (Polakovič, 1998a, s. 20). Przyjęte w wielu krajach rozwiązania prawne polegające na utożsamieniu narodowości z obywatelstwem prowadzą do różnych komplikacji związanych z przyznawaniem obywatelstwa. Ta sytuacja ma miejsce między innymi w Argentynie i Stanach Zjednoczonych, co związane jest z nie zrozumieniem istoty narodowości człowieka. Š. Polakovič utrzymuje bowiem, że narodowość jest niezniszczalnym znamieniem człowieka, będącym wyznacznikiem jego duchowości. Tego stygmatu nie można wymazać z duszy człowieka bez zniszczenia moralności osoby ludzkiej. Renegat był zawsze uważany za nikczemnika, stwierdził Š. Polakovič.

Różnice duchowości ludzkiej związane z narodowością są fundamentem istnienia wielu odmiennych narodów. W obrębie ludzkości istnieją społeczności, które niezależnie od istniejących państw funkcjonują jako odrębne narodowe społeczności. Posiadają one właściwe im cechy sprawiające, że tworzą one zbiorowości radykalnie różne od innych, pomimo tego, że wiele z nich nie jest politycznie zorganizowana. Te okoliczności przemawiają za tym, że musi istnieć siła spajająca owe społeczności przez stulecia, niezależnie od funkcji i roli państwa w tym zakresie, a pozwalająca zachować tym społecznościom poczucie tożsamości i odrębności narodowej (Polakovič, 1998a, s. 25).

Sposób istnienia narodów jest analogiczny do sposobu istnienia człowieka. Š. Polakovič przyjmuje, że entelechia właściwa człowiekowi wyraża się w tym, że jest on bytem duchowym, posiadającym duszę. Tak samo naocznie doświadczanym wyznacznikiem istnieniu narodu jest jego duchowość. Nie jest to jednak żaden czysty duch, lecz ucieleśnienie ludzkiej aktywności duchowej. Owo ucieleśnienie, trudne do wyrażenia w kategoriach dyskursywnych, dokonuje się poprzez realizację wartości duchowych, w których partycypuje każdy członek narodu. Zdaniem Š. Polakovicia układ wartości tworzących entelechie narodu dany jest jednostce ludzkiej w doświadczeniu intuicyjnym i emotywnym. Przejawia się to w tym, że członkostwo w narodzie jest bliskie sercu każdego człowieka. 
W filozoficznej refleksji Š. Polakovicia naród zajmował centralne miejsce. Dociekania dotyczące narodu Š. Polakovicia mają dwie odrębne fazy. Pierwsza obejmuje generalnie lata istnienia I Republiki Słowackiej, druga czasy emigracji. Mimo istotnych różnic związanych przede wszystkim z kontekstem politycznym twórczości Š. Polakovicia, koncepcje te łączy wiele wspólnych treści.

Š. Polakovič uznat, że czynnik konstytuujący istnienie narodu ma charakter transcedentalny. Natomiast samo jego określenie w twórczości autora uległo zasadniczym zmianom. W pierwszej fazie twórczości Š. Polakowič przyjąt, że to Absolut w rozumieniu chrześcijańskim, konstytuuje istnienie narodu. Konstytuowanie to jest związane ze stwórczym aktem woli Bożej i rolą, jaką naród ma zrealizować w dziejach ludzkości. W drugiej fazie twórczości transcedentalny aspekt tworzenia się i istnienia narodu sformułowany został bardzo ostrożnie. Transcedentalny charakter narodu powiązany został z fenomenem istnienia człowieka jako bytu duchowo-cielesnego. Supranaturalny fundament powstania i istnienia narodu został „przesunięty” tym samym na poziom ludzkiej duchowości jednostkowej i zbiorowej.

Specyficzna ludzka aktywność, jaką jest życie duchowe, realizowana może być tylko w określonym środowisku społecznym. Indywidualna duchowość jednostki kształtowana jest przez społeczeństwo, aby następnie sama jednostka wzbogacała kulturę, w której została wychowana. Zasadniczym miejscem kształtowania się jednostkowej i zbiorowej duchowości są narody. Ta zależność między duchowością człowieka i duchowością narodu sprawia, iż wszelkie definicje narodu naznaczone są skazą niepełności. Według autora pracy Náš duch brak adekwatnej definicji narodu wynika zarówno z ontycznej specyfiki narodu jak i trudności poznania narodu.

O ontycznej specyfice narodu przesądza jego pluralistyczny charakter. Pluralizm ten związany jest z różnymi sposobami istnienia poszczególnych elementów konstytuujących naród oraz dynamicznym charakterem rdzennej zawartości narodu. Uprawniona jest zatem konstatacja, iż w ujęciu Š. Polakovicia naród jest bytem idealno-realnym o dynamicznej zawartości rdzennej. Przy czym na zawartość rdzenną narodu składają się różnorodne artefakty i wartości kultury narodowej, które, tworzone i przetwarzane, przesądzają o ciągłości istnienia narodu.

Nośnikami kultury narodu istniejącej w sposób obiektywny i idealny, w której wyraża się duch narodu, są poszczególne społeczności narodowe. W koncepcji Š. Polakovicia naród jako specyficzna struktura społeczna ujmowana jest w kategoriach organizmu. Organicyzm ten, wyraźnie zaznaczony w pierwszej fazie twórczości Š. Polakovicia, został ograniczony na rzecz umiarkowanego atomizmu społecznego i indywidualizmu - w drugiej fazie twórczości.

Podstawowym elementem społeczności narodowej jest jednostka ludzka, która jako członek narodu jest naznaczona jego duchem, kulturą. Za taką interpretacją myśli Š. Polakovicia przemawiają jego twierdzenia. Zaliczyć do nich należy hipotezę o stworzaniu człowieka i narodów przez Boga. W całej swojej twórczości Š. Polakovič będzie podtrzymywał chrześcijańską koncepcję kreacyjnego aktu Boga. Drugą przesłanką jest zdecydowane przeciwstawienie narodu etnicznego narodowi politycznemu przez Š. Polakovicia. Filozof ten wręcz uważa, że pojęcie narodu politycznego pozostaje w sprzeczności z istotą narodu etnicznego i stanowi nadużycie intelektualne wywołujące wiele problemów i nieporozumień. Na rzecz umiarkowanego indywidualizmu, czy też atomizmu, przemawia twierdze- 
nie Š. Polakovicia, że naród jest przedłużeniem istnienia jednostek ludzkich. W koncepcji Polakovicia wyraża się to w genetycznej i substancjalnej interpretacji tej tezy. Naród jako szczególna wspólnota społeczna jest pochodną istnienia jednostek ludzkich.

Opowiedzenie się za umiarkowanym indywidualizmem prowadzi do pluralistycznej wi-

zji społeczności narodowej. Š. Polakovič dokonał szczegółowej analizy wkładu wielu twórców w kulturę narodu słowackiego, którzy nadali jej specyficzny charakter.

Ontyczna specyfika bytu, jakim jest naród, przesądza o możliwościach i metodach poznania narodu. Fakt, iż naród jest wspólnotą o zasadniczym znaczeniu dla człowieka sprawia, że poznanie narodu jako takiego napotyka zasadnicze trudności. Niemożliwość poznania narodu dotyczy przede wszystkim innego narodu. Ujawnia się ona w tym, iż inny, niebędący członkiem danego narodu, nie jest w stanie w pełni zrozumieć duchowości odrębnego narodu. Natomiast poznanie własnego narodu, a w szczególności jego duchowości, wykracza poza ramy wyznaczone specyfiką poznania kognitywnego i w swoim źródłowym wymiarze dane jest jako emotywna oczywistość. Tym samym Š. Polakovič opowiedział się po stronie emotywizmu i agnostycyzmu w odniesieniu do sposobu i możliwości poznania narodu.

Dociekania Š. Polakovicia dotyczące narodu były silnie naznaczone uwarunkowaniami politycznymi. Koncepcja narodu rozwijana przez Š. Polakoviča w okresie funkcjonowania I Republiki Słowackiej była podporządkowana w znacznym stopniu doraźnym celom społecznym i politycznym Na jej kształt istotny wpływ miały spory dotyczące kształtu ustrojowego państwa słowackiego prowadzone przez ówczesną elite polityczną. Pozostając w opozycji do skrajnie faszystowskiej koncepcji państwa Vojtecha Tuki, Š. Polakovič doprowadził do maksymalnego, przynajmniej w warstwie teoretycznej, zneutralizowania ideologii niemieckiego faszyzmu. Temu zagadnieniu poświęcił obszerną rozprawę zatytułowaną Slovenský národný socializmus - Ideové poznámky (Polakovič, 1941a). W okresie pobytu na emigracji w Argentynie dociekania Š. Polakovicia nad narodem są w znacznym stopniu wolne od ideologicznych i politycznych sporów. Wyrazem tego jest projekt nacjologii, jako nauki filozoficznej.

\section{BIBLIOGRAFIA}

Bakoš, V. (1985). Kapitoly z dejin slovenského muslenia. Bratislawa: Polygrafia SAV.

Balážová, J. (1998). Primordialistická koncepcia národa Štefana Polakoviča. W J. Michalov (Red.), Dejiny filozofie na Slovensku v XX. storočí. Bratislava: Herba.

Balážová, J., Kollár, K., \& Pichler, T. (Red.). (1996). Súčasné podoby filozofie a filozofovania na Slovensku. Bratislava: Infopress.

Bobák, J. (Red.). (1995). Slovenský politický exil v zápase za samostatné Slovensko - Materiály z vedeckej konferencje. Bratislava: Dom zahraničných Slovákov.

Chmel, R. (Red). (1997). Slovenská otázka v 20. storočí. Bratislawa: Kalligram.

Mihalik, M. (2000). Národ a dejinnost’ v ponímaní Polakoviča a Heideggera. Acta Culturologica, 5.

Polakovič, Š. (1941a). Slovenský národný socializmus - Ideové poznámky. Bratislava: Matica Slovenská.

Polakovič, Š. (1941b). Tisova náuka. Bratislava: Hlinkova slovenská l'udová strana.

Polakovič, Š. (1994a). Naše korene v základoch Európy. Martin: Matica slovenská. 
Polakovič, Š. (1994b). Obnova národa duchom Štúra. Bratislava, Štúrova spoločnost.

Polakovič, Š. (1998a) Eseje o národe. Martin: Matica slovenská

Polakovič, Š. (1998b). Kultúra je pre národ otázkou života.

Polakovič, Š. (1998c). Podstata národa je v kultúre. Š. Polakovič. Eseje o národe. Martin: Matica slovenská.

Sedlák, I. (Red). (1997). L'udovit Štúr v súradniciach minulosti a súčasnostti. Martin: Matica Slovenská. 